\title{
Pemberdayaan Kader Dalam Upaya Deteksi Dini Stunting di Kutu Kembangan Sidomulyo Bambanglipuro Bantul
}

\author{
Luluk Khusnul Dwihestie $^{1 *}$, Ririn Wahyu Hidayati ${ }^{2}$ \\ 1,2Fakultas IImu Kesehatan Universitas 'Aisyiyah Yogyakarta
}

\section{INFORMASI ARTIKEL:}

Riwayat Artikel:

Tanggal diterima: 25 Juni 2021

Tanggal di revisi : 20 Juni 2021

Tanggal di Publikasi : 30 Juni 2021

Kata kunci:

stunting, pemberdayaan kader posyandu

Keyword:

Stunting, empowerment of posyandu cadres

\section{Pendahuluan}

Masalah gizi di Indonesia dan di negara berkembang lainnya masih didominasi oleh

\section{ABSTRAK}

Latar Belakang : Persoalan gagal tumbuh pada anak (stunting) masih menjadi tantangan dalam pembangunan sumber daya manusia di Indonesia. Tahun 2020, angka kejadian stunting pada balita di Indonesia masih cukup tinggi, yakni 27,67 persen. Kasus stunting ini perlu mendapatkan perhatian, sebab stunting dapat berdampak pada kelainan tumbuh kembang anak secara irreversible (tidak dapat diubah), terganggunya fungsi kognitif, motorik, serta proses metabolisme, bahkan dapat menurunkan konsentrasi belajar. Pemerintah menargetkan penurunan angka stunting hingga 14 persen pada 2024. Untuk mempercepat penurunan stunting, Puskesmas dan Posyandu mempunyai peran penting dalam memantau pertumbuhan balita. Kegiatan pengabdian masyarakat ini bertujuan untuk meningkatkan pemberdayaan kader posyandu dalam deteksi dini stunting pada balita. Metode pelaksanaan : Tahap persiapan dan koordinasi, pelaksanaan sosialisasi, simulasi dan evaluasi cara pengukuran tinggi badan balita. Para kader posyandu antusias mengikuti pelatihan deteksi dini stunting sebagai sarana peningkatan pengetahuan dan ketrampilan terkait cara pengukuran tinggi badan balita secara benar dan tepat, serta mampu menganalisis hasil pengukuran dan mengkategorikan balita stunting atau tidak stunting. Diharapkan kader posyandu dapat mengedukasi orangtua balita di wilayah Kutu Kembangan untuk rutin mengikuti posyandu guna memantau tumbuh kembang balita.

Background :The impairment of grow in children (stunting) is still a challenge in the development of human resources in Indonesia. In 2020, the incidence of stunting in toddlers in Indonesia is significantly high, which is shown at 27.67 percent. This stunting case needs attention, because stunting has an irreversible impact on children's growth and development disorders, disrupt cognitive, motor, metabolic functions, even reduce learning concentration. The government targets a reduction in stunting rates to 14 percent by 2024 . To accelerate stunting reduction, Puskesmas and Posyandu have an important role in monitoring the growth of toddlers. This community service activity aims to increase the empowerment of posyandu cadres in early detection of stunting in toddlers. The method of implementing the activity is to explain the solutions offered to overcome partner problems, through the preparation and coordination stages, implementation of socialization, simulation and evaluation of how to measure toddlers' height. Posyandu cadres enthusiastically participated in stunting early detection training as a means of increasing knowledge and skills related to how to measure toddlers' height correctly and precisely, as well as being able to analyze measurement results and categorize stunted or non-stunted toddlers. It is hoped that the posyandu cadres can educate parents of toddlers in the Kutu Kembangan area to regularly attend the posyandu to monitor the growth and development of toddlers.

\footnotetext{
${ }^{*}$ Korespondensi penulis.

Alamat E-mail: anonim@mail.com
}

masalah malnutrisi. Malnutrisi merupakan masalah yang membutuhkan perhatian khusus, karena merupakan faktor resiko 
penting terjadinya kesakitan dan kematian pada ibu hamil dan balita (Krisnansari, 2010). Salah satu masalah gizi cukup besar dan belum terselesaikan adalah stunting.

Stunting adalah masalah kurang gizi kronis yang disebabkan oleh asupan gizi yang kurang dalam waktu cukup lama akibat pemberian makanan yang tidak sesuai dengan kebutuhan gizi $(\mathrm{WHO}, 2012)$. Balita stunting adalah balita dengan status gizi yang berdasarkan panjang atau tinggi badan menurut umurnya bila dibandingkan dengan standar baku WHO-MGRS (Multicentre Growth Reference Study) tahun 2005, nilai z-scorenya kurang dari -2SD (WHO, 2013) dan dikategorikan sangat pendek jika nilai zscorenya kurang dari -3SD (Millennium Challenga Account Indonesia, 2014). Stunting digunakan sebagai indikator malnutrisi kronik yang menggambarkan riwayat kurang gizi anak dalam jangka waktu lama sehingga kejadian ini menunjukkan bagaimana keaadaan gizi sebelumnya (Kartikawati, 2011).

Stunting dapat mengakibatkan kerusakan pada perkembangan anak yang irreversible (tidak bisa diubah), anak tersebut tidak akan pernah bisa mempelajari dan mendapatkan sebanyak yang dia bisa (Trihono, 2015). Konsekuensi jangka pendek yang diakibatkan stunting yaitu meningkatkan mortalitas dan morbiditas, terganggunya fungsi kognitif, motorik, terganggunya proses metabolisme dan meningkatkan pengeluaran untuk biaya perawatan anak sakit. Sedangkan efek jangka panjangnya adalah menurunkan prestasi sekolah, menurunkan kapasitas belajar, perawakan pendek ketika dewasa, obesitas, penurunan kapasitas kerja dan penurunan produktivitas (Stewart et al, 2013).

Prevalensi balita pendek menjadi masalah kesehatan masyarakat jika prevalensinya $20 \%$ atau lebih $(\mathrm{WHO}, 2014)$.
Berdasarkan Pemantauan Status Gizi (PSG) (2017) prevalensi stunting di Indonesia (29.6\%) lebih tinggi daripada negara-negara lain di Asia Tenggara, seperti Myanmar (25\%), Vietnam (23\%), dan Thailand (16\%). Provinsi Daerah Istimewa Yogyakarta termasuk presentase yang kejadian stunting cukup tinggi, dengan prevalensi balita pendek ditahun 2017 yakni 13,86\% (Dinkes DIY, 2017).

Penentuan stunting tidak lepas dari pengukuran antropometri yang akurat dan berkelanjutan. Hal ini penting untuk evaluasi klinik pertumbuhan anak, dan kecepatan pertumbuhan tinggi badan (TB) anak pada masa remaja, dapat dibandingkan tinggi badan anak dengan tinggi badan orangtuanya atau digunakan baku/ stantar tertentu yang di berlaku di populasi tersebut (Ranuh, et al, 2015).

Guna melakukan skrining tenaga kesehatan memiliki tangan panjang yaitu kader posyandu. Kader posyandu yang telah dibekali atau dilatih terkait pemeriksaan antropometri dapat menjalankan tugasnya untuk melakukan pemeriksaan antropometri, wbg upaya deteksi dini stunting pada balita pada saat posyandu berlangsung. Berdasarkan studi pendahuluan, didapatkan informasi bahwa pelatihan terkait penentuan stunting oleh kader posyandu balita dilakukan hanya perwakilan kader dari masingmasing posyandu. Sehingga belum semua kader terpapar pelatihan tersebut. Kader yang telah mendapatkan pelatihan akan menyampaikan kepada rekan kader yabg lain (peer group) terkait cara pemeriksaan. Hal ini merupakan salah satu upaya agar seluruh kader dapat melakukan pemeriksaan antropometri.

Namun pada kenyataannya, pada saat dilakukannya observasi dalam melakukan pengukuran antropometri masih kurang tepat. Misalnya beberapa kader melibatkan pengasuh atau orang tua untuk mengukur tinggi badan 
anaknya sendiri. Ada pula kader yang mengukur tinggi badan anak menggunakan pita ukur yang di panjangkan dari kepala hingga kaki mengikuti lekuk tubuhnya. Kondisi ini dapat memberikan hasil pemeriksaan yang tidak akurat untuk mendiagnosa stunting.

\section{Metode}

Metode pelaksanaan kegiatan menjelaskan solusi yang ditawarkan untuk mengatasi permasalahan yang dilakukan adalah rekrutmen, pelatihan, pendampingan dan memberikan pendidikan kesehatan untuk mitra. Langkah-langkah yang dilakukan adalah:

1. Melakukan survey analisis masalah.

2. Bekerjasama dengan ketua kader posyandu balita untuk mengadakan pertemuan dengan kader posyandu balita setempat untuk melihat gambaran konkret.

3. Sosialisasi, simulasi dan pendampingan tentang deteksi dini stunting kepada seluruh kader posyandu balita di wilayah Kutu Kembangan.

4. Evaluasi hasil pendampingan dan memotivasi kader posyandu untuk lebih optimal dalam pemantauan deteksi dini stunting dengan melibatkan orangtua balita.

\section{Hasil dan Pembahasan}

Pelaksanaan kegiatan pengabdian masyarakat ini diawali dengan rapat koordinasi bersama Ketua kader posyandu balita di wilayah Kutu Kembangan, membahas tentang persiapan simulasi deteksi dini stunting kepada kader posyandu dan pendampingan secara langsung cara pengukuran tinggi badan balita dengan tepat.

Selanjutnya, penyampaian pendidikan kesehatan tentang deteksi dini stunting pada kader posyandu, simulasi dan pendampingan praktik secara langsung cara deteksi dini stunting dengan pengukuran tinggi badan yang tepat.

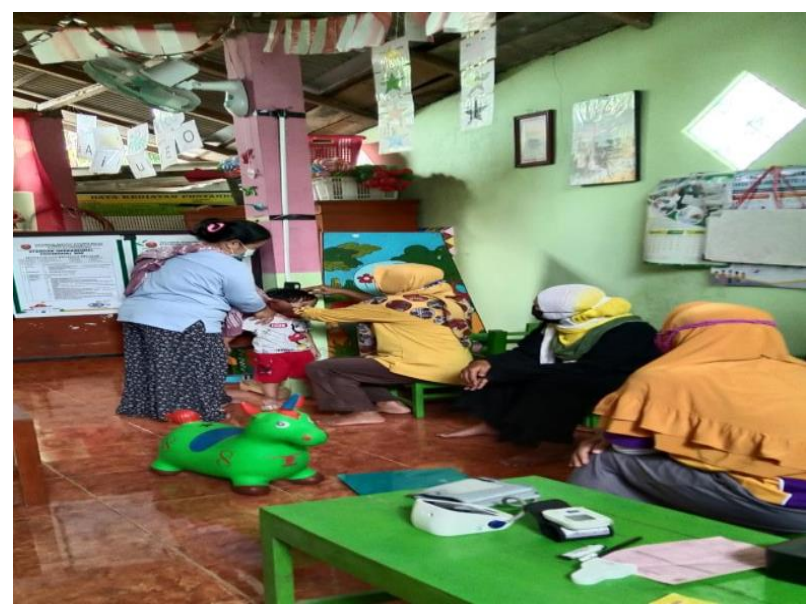

Gambar 1. Simulasi dan pendampingan pengukuran tinggi badan anak

Pendampingan praktik dilakukan saat pelaksanaan posyandu. Dikarenakan masa pandemi covid-19 pelaksanaan posyandu dilakukan dengan cara kader kunjung rumah. Melalui pendampingan secara langsung kepada kader posyandu, dapat diketahui tindakan mana yang belum benar dan dapat melakukan pembenaran saat melakukan pemeriksaan. Selanjutnya kader langsung bisa memperbaiki pada pemeriksaan balita berikutnya.

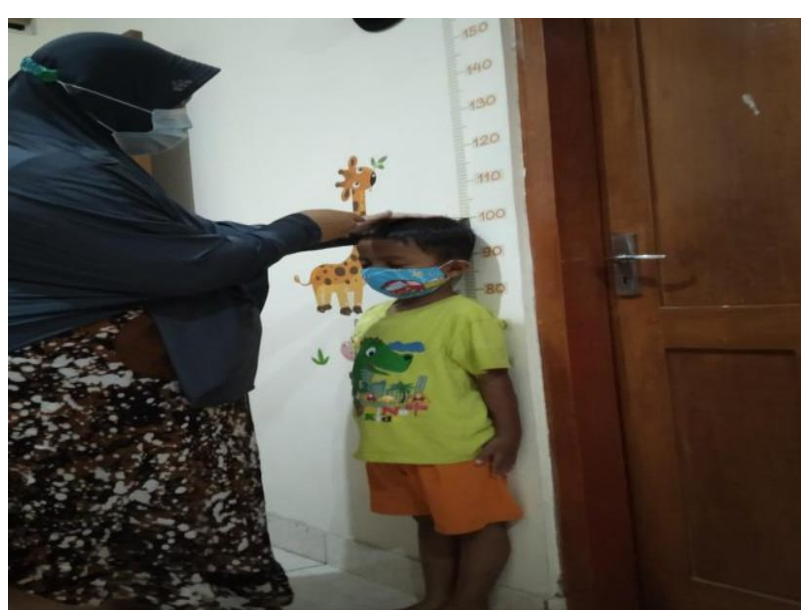

Gambar 2. Praktik pengukuran tinggi badan anak oleh kader posyandu

Tahap akhir yaitu evaluasi terhadap aspek kognitif, afektif/sikap, dan psikomotor 
kader posyandu setelah diberikan sosialisasi dan pendampingan. Serta memotivasi keberlanjutan program deteksi dini stunting pada balita di wilayah setempat dengan melibatkan orangtua balita.

Pelaksanaan pelatihan mengenai stunting pada balita memberikan pengaruh positif terhadap peningkatan pengetahuan dan kemampuan kader posyandu balita dalam mempraktikkan pengukuran tinggi badan. Hal ini sesuai dengan teori Notoatmodjo (2010) bahwa seseorang dapat melakukan praktik dengan baik melewati beberapa tingkatan. Tingkatan pertama yaitu persepsi, seseorang mulai mengenal dan memilih berbagai objek sehubungan dengan tindakan yang akan diambil. Kedua, respon terpimpin yaitu seseorang dapat melakukan sesuatu sesuai dengan urutan yang benar dan sesuai contoh yang diberikan saat pelatihan. Ketiga, mekanisme yaitu apabila seseorang telah dapat melakukan sesuatu dengan benar secara otomatis dan menjadi kebiasaan. Dalam hal ini kader posyandu balita sudah dapat melakukan pengukuran tinggi badan dengan tepat. Keempat, adopsi yaitu suatu praktik yang sudah berkembang dengan baik, artinya tindakan itu sudah dimodifikasi tanpa mengurangi kebenaran tindakan tersebut. Kader posyandu balita sudah dapat menganalisis hasil pengukuran tinggi badan balita untuk mendeteksi adanya stunting.

Salah satu cara untuk mengetahui sejauh mana kefektifan pelatihan ini adalah dengan evaluasi. Kader diberi kesempatan untuk menyimpulkan materi yang telah disampaikan, mulai dari pengertian stunting, cara pencegahan dan penanggulangan balita stunting. Modul yang diberikan saat pelatihan digunakan sebagai panduan dalam melakukan pengukuran tinggi badan, dan kader posyandu balita dapat mempraktikkan setiap langkah- langkah dengan benar. Hal ini menunjukkan bahwa dengan adanya pelatihan dapat meningkatkan pengetahuan dan ketrampilan kader dalam mendeteksi dini stunting pada balita serta dapat mengetahui rencana tindak lanjut apabila terjadi stunting pada balita.

\section{Simpulan}

Kegiatan pengabdian masyarakat ini didapatkan hasil bahwa meningkatnya pengetahuan dan ketrampilan kader posyandu balita dalam melakukan pengukuran tinggi badan balita. Meskipun sedang masa pandemic covid-19, namun di wilayah Kutu Kembangan tetap dilaksanakan posyandu balita dengan cara kader mendatangi rumah balita satu per satu. Kegiatan yang dilakukan yaitu pengukuran tinggi badan dan penimbangan berat badan, serta pemberian makanan tambahan (PMT) bagi balita.

\section{Ucapan terima kasih}

Ucapan terima kasih dihaturkan kepada Universitas 'Aisyiyah Yogyakarta yang telah memberikan dana hibah untuk pelaksanaan kegiatan pengabdian masyarakat ini. Sekaligus kepada ibu-ibu kader posyandu balita Kutu Kembangan Sumbermulyo Bambanglipuro Bantul yang telah bersedia bekerjasama dalam kegiatan pengabdian masyarakat.

\section{Daftar Pustaka}

Dinkes DIY. (2017). Profil Kesehatan Provinsi Di Yogyakarta Tahun 2017. (online) http://www.depkes.go.id/resources/do wnload/profil/PROFIL_KES_PROVI NSI_2017/14_DIY_2017.pdf diakses pada tanggal 15 Oktober 2019 pukul 19.20 WIB.

Kartikawati, P. (2011). Faktor Yang Mempengaruhi Kejadian Stunted Growth Pada Anak Balita Di Wilayah 
Kerja Puskesmas Arjasa Kabupaten Jember. Skripsi: Jember.

Krisnasari, Dyah. (2010) Nutrisi dan Gizi Buruk. Jurnal Mandala of Health Fakultas Kesehatan Universitas Jendral Soedirman, Vol.4(1), 60-68

MCA-Indonesia. (2014). Stunting dan Masa Depan Indonesia terdapat dalam www.mca-indonesia.go.id diakses pada tanggal 15 Oktober 2019.

Stewart CP, Iannotti L, Dewey KG, Michaelsen KF \& Onyango KW. (2013) Contextualising Complementary Feeding In a Broader Framework For Stunting Prevention. Journal University Of California, Vol.9(2), 27-45.

Trihono. (2015). Pendek (Stunting) di Indonesia, Masalah dan Solusinya. Jakarta: Badan Penelitian dan Pengembangan Kesehatan.

WHO/NCS. (2012). Badan Penelitin dan Pengembangan Kesehatan Kementerian Kesehatan RI . Jakarta: Riset Kesehatan dasar RI.

World Health Organization (WHO). (2014). WHO Global Nutrition targets 2025: Stunting policy brief. Geneva: World Health Organization 